\title{
Porous Concrete for Pedestrian Pavements
}

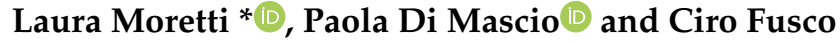 \\ Department of Civil, Constructional and Environmental Engineering, Sapienza University of Rome, \\ Via Eudossiana 18, 00184 Rome, Italy; paola.dimascio@uniroma1.it (P.D.M.); ciro.fusco@uniroma1.it (C.F.) \\ * Correspondence: laura.moretti@uniroma1.it; Tel.: +39-064-458-5114
}

Received: 17 July 2019; Accepted: 8 October 2019; Published: 10 October 2019

\begin{abstract}
Changes in weather patterns directly impact urban transport infrastructures. The increase in temperature and the ongoing precipitation changes should be handled and managed more frequently. In urban areas, most of the soil is impermeable and water hardly infiltrates into the subsoil. Permeable pavement is a technology that helps mitigate the effects of urban heat islands and surface impermeabilization. Porous concrete for pedestrian pavements ensures good structural, functional, and environmental performances. A pervious concrete mix differs from a conventional one in terms of the gradation of aggregates, namely, a lack of fine aggregates. The material porosity (on average $20 \%$ ) causes compressive and flexural strengths lower than those of traditional concrete. The material is suitable for low-load pavements where the passage of motorized vehicles is forbidden or occasional. The pavement can be laid either monolithically or modularly, using two operating systems: returning water to underground aquifers and reducing runoff. The latter is the most frequently adopted in urban areas, where pedestrian and interdicted to motorized vehicle areas form a continuous and distributed network. In a common urban quarter, where $80 \%$ of the surface is impermeable, porous concrete pavements could cover up to $6 \%$ of the surface and provide architectural and aesthetic value for the environment.
\end{abstract}

Keywords: pedestrian pavement; sidewalks; porous concrete; porous paver; block pattern; urban heat island; rainwater management system; sustainable urban drainage system

\section{Introduction}

Soil in anthropized areas is almost completely impermeable and water hardly infiltrates into the subsoil, a condition which amplifies the effects of rainfall [1]. In recent years, "extreme rainfall events" have often occurred as consequence of the "flash flood" phenomenon: storms and floods follow heavy heat waves and long periods of drought. In natural soil, $40 \%$ of total rainwater evapotranspires, $50 \%$ infiltrates, and only $10 \%$ runs off [2]. On the other hand, less than half of urban areas have permeable surfaces. A recent study performed by [3] on a quarter in Rome demonstrated that only $20 \%$ of the surface is permeable (green areas in Figure 1a). In such conditions, up to $55 \%$ of total rainwater on average runs off and only $15 \%$ infiltrates. This balance is even more critical because permeable surfaces are often not distributed throughout the territory. 


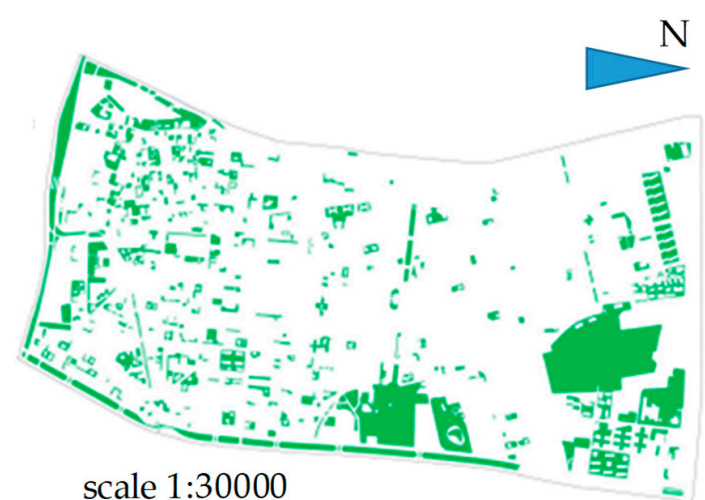

(a)

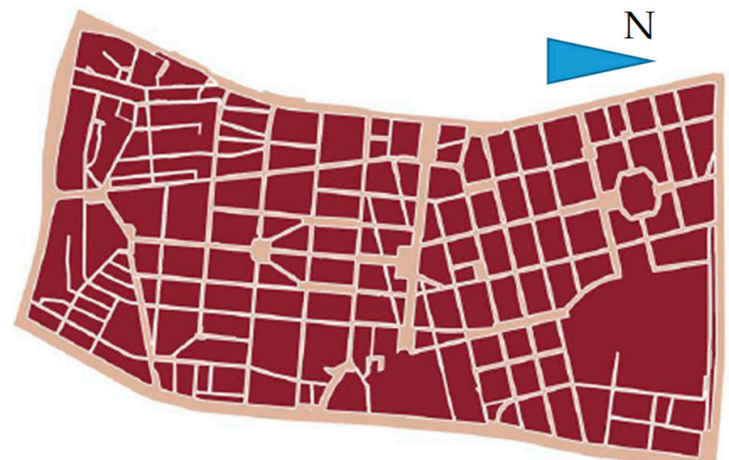

scale 1:30000

(b)

Figure 1. Map of a quarter in Rome: (a) permeable areas (green) and (b) road network (light brown).

The road network in the urban area in Figure 1a covers $24 \%$ (light brown areas in Figure 1b) of the overall surface, of which $21 \%$ is impermeable and only $3 \%$ is permeable surface.

Therefore, the road network could play a key role in handling and managing the ongoing weather and precipitation changes. Permeable pavements could provide important benefits and mitigate the consequences of urbanization. In the United States and Australia, they represent a technology that can reduce the impacts of anthropization in urban areas [4-6]. The use of permeable pavements complies with the Italian Decree on Minimum Environmental Criteria (MEC) for public works, which contains criteria that should be included as part of public bids [7]. It identifies a set of MEC for contracts related to reducing soil consumption and maintaining soil permeability when new public buildings or urban renovation projects are designed. Specifically, each project should provide a permeable surface not less than $60 \%$ of the overall project surface (e.g., green surfaces, pavements with open meshes or grid elements, etc.). Moreover, the use of porous materials with a solar reflectance index (SRI) not less than 29 is requested for urbanized pedestrian and cycle surfaces. Whenever pavements are replaced and the use of green surfaces is not feasible, "cold" materials should be used (e.g., white stones, reinforced lawn, soil, paving grids for grass parking lots, light stone, cobblestone, gravel, wood, limestone, and permeable self-locking blocks).

Regarding pedestrian pavements, the most used materials differ in their physical and mechanical characteristics [8], as described below.

- Gravel: It is considered to be an unpaved road which generally provides the lowest level of service to users. It is usually composed of 6-20 mm aggregates, with up to $20 \%$ voids. To achieve a regular surface, the runoff coefficient of which ranges between 0.30 and $0.50,4-8 \mathrm{~cm}$ thick layers are roller compacted; its structural and functional success depends on the geotechnical characteristics of the bottom layer.

- Mastic asphalt: It is a mixture composed of bitumen binder, stone filler, and mineral powder heated and mixed in the hot state. It is pourable in place and suitable for manual laying on the subgrade. The mixture has a low void content. The percentage content of bitumen is higher than in asphalt mixtures (i.e., up to $8 \%$ ); therefore, a slight excess of binder may occur and cause bleeding. This material provides an up to $30 \mathrm{~mm}$ thick continuous and waterproof lining to protect the subgrade against rainwater.

- Porous mastic asphalt: It is a bituminous mixture, the grading aggregate of which results in a $10 \%-15 \%$ void content. It meets the needs for an impermeable and compacted bottom layer.

- Stone pavers: They are used for pedestrian and urban low-volume traffic pavements in historic city neighborhoods and towns [9], where their architectural and environmental impact is desirable [10].

- Reinforced lawn: It allows grass to be incorporated into a plastic grid paver to provide a permeable surface. The relatively thin depth of these systems and their inherent flexibility do not permit load 
carriage on this surface. Its permeability depends on the geometry and pattern of the elements and the filling material (e.g., natural soil or gravel).

- Porous concrete: It is composed of a pervious concrete surface with a $15 \%-25 \%$ void content laid on a granular foundation. The pavement structure is composed of an $8-10 \mathrm{~cm}$ thick surface layer. Its use is possible in the absence of a water-sensitive subsurface.

- Concrete pavers: They have voids at the joints to allow water to pass through. As for porous concrete, it should have adequate subsurface conditions to detain stormwater and a level bottom to allow for uniform infiltration into an open-graded reservoir below. Concrete grid pavers are a type of open-cell modular pavement, the cells of which are filled with soil and grass; up to $40 \%$ of the paved surface could be permeable [11].

The examined different technical characteristics reflect the different structural, functional, and environmental performances of pedestrian infrastructures. The material choice depends on often conflicting requirements:

- Asphalt is the most frequently used material to pave sidewalks in urban areas because it ensures good results in terms of regularity, adherence, and cost effectiveness of the investment, and it is quick to build, allowing for traffic to swiftly reopen. However, it suffers from environmental impacts due to its impermeability, low SRI, and difficulty in obtaining a good fitting in the surrounding environment [12].

- Porous concrete ensures good technical and environmental performances due to the mechanical, physical, and thermal characteristics of the material. However, it suffers from high cost of installation and waiting time for traffic to reopen.

- Reinforced lawn presents certain issues because its modular geometry requires more time to build than monolithic surfaces, and its durability and possible carriage capacity (e.g., in the presence of driveway) depend on the characteristics of the material used. Moreover, its functional, economic, and environmental results are never appreciable.

- The less-impacting solution (i.e., gravel) is not compatible with the needs of users (e.g., low level of service, not powder free, non-weather-conditioned usability) and infrastructure managers (e.g., maintenance costs). However, gravel provides for a "cold", eco-friendly, and permeable pavement.

Table 1 summarizes the good, fair, and poor performances of the most frequently used materials with green, orange, and red symbols, respectively. All data refer to conventional performances of each material (e.g., white asphalt, pervious concrete pavers, and concrete grid pavers are not considered).

In recent years, pervious concrete, both monolithic and modular, has been increasingly used because of its environmental and landscape value in anthropized areas. Doulos et al. [13] recognized the thermal characteristics of pavement materials as a strategic challenge to prevent urban heat islands (UHIs) and to cool urban spaces. Coseo et al. [14] compared the air temperature above reflective and pervious concrete, pervious and conventional asphalt, and pervious modular concrete pavements, and porous concrete pavers were the only cool pavement strategy to yield lower early evening air temperatures relative to conventional asphalt. Pavement porosity has two more implications: (1) the presence of voids reduces the compressive strength of the material and (2) permits stormwater storage [15]. Therefore, permeable pavements are primarily used in parking lots, pedestrian areas, cycle paths, and other low-traffic areas [16].

In this review, we analyzed the technical and functional characteristics of pervious concrete pavements for sidewalks or pedestrian paths which use both monolithic and modular technologies. 
Table 1. Structural, functional, and environmental performances of materials for pedestrian pavements. Green, orange, and red symbols represent good, fair, and poor performances, respectively.

\begin{tabular}{|c|c|c|c|c|}
\hline Property & Asphalt & Gravel & Reinforced Lawn & Porous Concrete \\
\hline Regularity & & & $\because$ & \\
\hline Adherence & & & $\because$ & \\
\hline Non-weather-conditioned usability & & & $\because$ & \\
\hline “Cold” material & & & & \\
\hline Powder free & & & $\because$ & \\
\hline Sidewalk-environment fit & & & $\because$ & \\
\hline Fast to build & & $=$ & & \\
\hline Fast reopening of traffic & & & & \\
\hline Durability & & & & \\
\hline Carriage capacity & $=$ & $\because$ & & \\
\hline Cost of installation & & & $\because$ & \\
\hline Low maintenance & $\because$ & & $\because$ & \\
\hline Eco-friendliness & $\because$ & & $\because$ & $\because$ \\
\hline Water management & & & $\because$ & ; \\
\hline
\end{tabular}

\section{Research Methodology}

In this study, a systematic literature review was performed according to Kitchenham [17]: primary studies contributed to the present manuscript, which is a secondary study. The goal of the study was to identify and analyze research relevant to technical and functional characteristics of porous concrete pavements for low-traffic surfaces in urban areas.

Peer-reviewed articles on sustainable urban drainage systems (SUDSs) composed of monolithic and modular porous concrete pavements, published between 2007 and 2019, were included. The main search strategy was automatic and involved Scopus and Web of Science peer-reviewed databases; a manual search activity involved peer-reviewed papers published since 2004. Finally, classical sources, standards, and regulations were considered, whatever their publication year. The considered keywords were permeability, porous (or permeable) pavement, porous (or permeable, or pervious) concrete, modular pavement, pavers (or concrete blocks), stormwater management, sustainable urban drainage, vulnerability, and urban roads.

Planning, conduction, and reporting results are the three main phases of the systematic literature review:

- Planning: identification of the need which justifies the systematic literature review. Particularly, the research questions are

How do stormwater management criticalities interfere with urban life?

$0 \quad$ Which pavement materials are used at the international level to manage runoff and prevent flooding?

- What are the pros and cons of porous concrete pavements (monolithic and modular) adopted by road agency bodies? 
- Conduction: implementation of a search strategy compliant with the previous phase.

- Reporting results: description of the results, answers to the goal of the study, and discussion of the results [18].

The work selection strategy identified 50 documents, which are cited in the reference list: 32 are primary studies (i.e., peer-reviewed indexed research papers); 6 are secondary studies (i.e., review papers); and 12 are guidelines, standards, or regulations. Overall, 37 research and review papers published after 2007 were included.

These works permitted us to make a critical assessment of the state of the art and answer the research questions.

\section{Materials and Construction}

Porous concrete is a special mix of cementitious concrete with high porosity used for concrete pavement applications that allows meteoric water to pass directly through, thereby reducing runoff.

The basic ingredients of a pervious concrete mix do not differ from a conventional concrete mix, except for their proportion. Indeed, the permeability of pervious concrete is provided by the gradation of the aggregates: there is a lack of fine aggregates, and the cementitious paste coats large aggregates, allowing water to pass through the voids:

- Aggregates: The aggregate gradation typically consists of single-sized or a binary mixture of coarse aggregates and it has a significant influence on the properties of pervious concrete. Coarse aggregates range between 9 and $19 \mathrm{~mm}$, while fine aggregates (less than $10 \%$ by weight of total aggregates) are added to increase the strength of the concrete, but they gradually reduce the void content [19].

- Cement: Various types of cement can be used (e.g., Portland cement, blended cement, and slag cement). Its content seriously affects the compressive strength and void structure of the layer. The optimum cement content depends on the aggregate size and gradation and it ranges between 260 and $415 \mathrm{~kg} / \mathrm{m}^{3}$. The aggregate-to-cement $(\mathrm{a} / \mathrm{c})$ ratio ranges between $4: 1$ and 10:1 as the required compressive strength decreases and the permeability rate increases [20].

- Water: The water-to-cement ratio $(\mathrm{w} / \mathrm{c})$ usually ranges between 0.28 and 0.40 to provide sufficient coating for aggregates. According to Eathakoti et al. [21], the ideal w/c value for no-fines concrete mixes is 0.45 .

- Admixtures: Chemical admixtures are used to obtain or enhance specific properties of the mixture; viscosity modifying, air entraining, retarder, and water reducer agents are the most frequently used. Pigments are added to fresh mixtures to enhance sidewalk integration with most surrounding landscape and architectural elements. Fibers could be added to obtain significant improvement in the compressive strength [22].

The compressive strength of pervious concrete usually varies between 4 and $28 \mathrm{MPa}$, while the flexural strength ranges between 2 and $4 \mathrm{MPa}$. These values are lower than those of traditional concrete because of the material porosity [23]. Such strength values make the material suitable for low-load pavement as sidewalks, pedestrian areas, and urban shared areas where occasional passages of commercial and heavy vehicles may occur [24].

Regarding the hydraulic performance of porous concrete, an Italian guideline defines five levels of capacity for drainage (Table 2) [25]. 
Table 2. Capacity for drainage.

\begin{tabular}{cc}
\hline Level & Capacity for Drainage $\left(\mathbf{l} / \mathbf{m}^{\mathbf{2}} / \mathbf{m i n}\right)$ \\
\hline Very high & $>500$ \\
High & $>300$ \\
Normal & $>100$ \\
Low & $>50$ \\
Very low & $<50$ \\
\hline
\end{tabular}

Porous concrete typically has a normal-high capacity for drainage, which is comparable to that of clean loose gravel. This value of capacity for drainage corresponds to high values of the surface infiltration rate (SIR) calculated according to the standard ASTM D3385-03 [26]. Although the infiltration capacity decreases with a prolonged storm, the SIR is suitable for predicting infiltration from a severe precipitation event. Regarding porous concrete, its average value (up to $800 \mathrm{~mm} / \mathrm{h}$ ) is comparable to that of natural soil [27]. According to the European standard UNI EN 12697-40 [28], the permeability values of porous concrete range between $5.78 \times 10^{-3}$ and $2.69 \times 10^{-2} \mathrm{~m} / \mathrm{s}$.

When it rains, the voids fill up and water flows through the material. The rainwater management system could follow two structural and hydrological operating systems (Figure 2):

1. Returning water to underground aquifers $[29,30]$ : This approach is possible when the natural soil is permeable, and the water does not transport pollutants (e.g., particulates and heavy metals from exhaust fumes, copper from brake pads, tire deposits, drips of oil, grease, antifreeze, hydraulic fluids, and cleaning agents) that could contaminate the hydraulic and marine environment [31].

2. Reducing runoff [32] and collecting water in retention basins in order to manage suspended solids and pollutants: Due to the potential transport of contaminants, this is the most frequently adopted choice for road surfaces. Along with atmospheric contaminants, high concentrations of harmful pollutants (e.g., hydrocarbons, lead, and copper) can be in water runoff [33]. In the literature [34,35], porous pavements have been investigated as a system for removing urban runoff of both organic and inorganic pollutants (e.g., sediments, heavy metals, nutriments, pathogens). They act as filters that capture most of the polluting elements and treat the water through interception, filtration, sedimentation, nutrient transformation, and microbial removal. SUDSs depend on the porosity and geometry (i.e., modular or monolithic) of the surface layer, the geotechnical characteristics of the bottom layers, and the rainfall intensity; particularly, the intensity of rainfall affects both pollutant loadings and reductions. Therefore, the water quality benefits vary according to the environmental conditions. Some of the most common pollutants are hydrocarbons. They are treated by biodegradation and physical entrapment and stored over the long term; heavy metals are stored inside the structure for the service life of the pavement. Charlesworth et al. [36] investigated the potential impacts of released contaminants on the environment and human health during maintenance procedures and found that their accumulation does not imply an environmental pollution risk when carrying out pavement maintenance and rehabilitation work. Moreover, the materials could be recycled at end of life. 


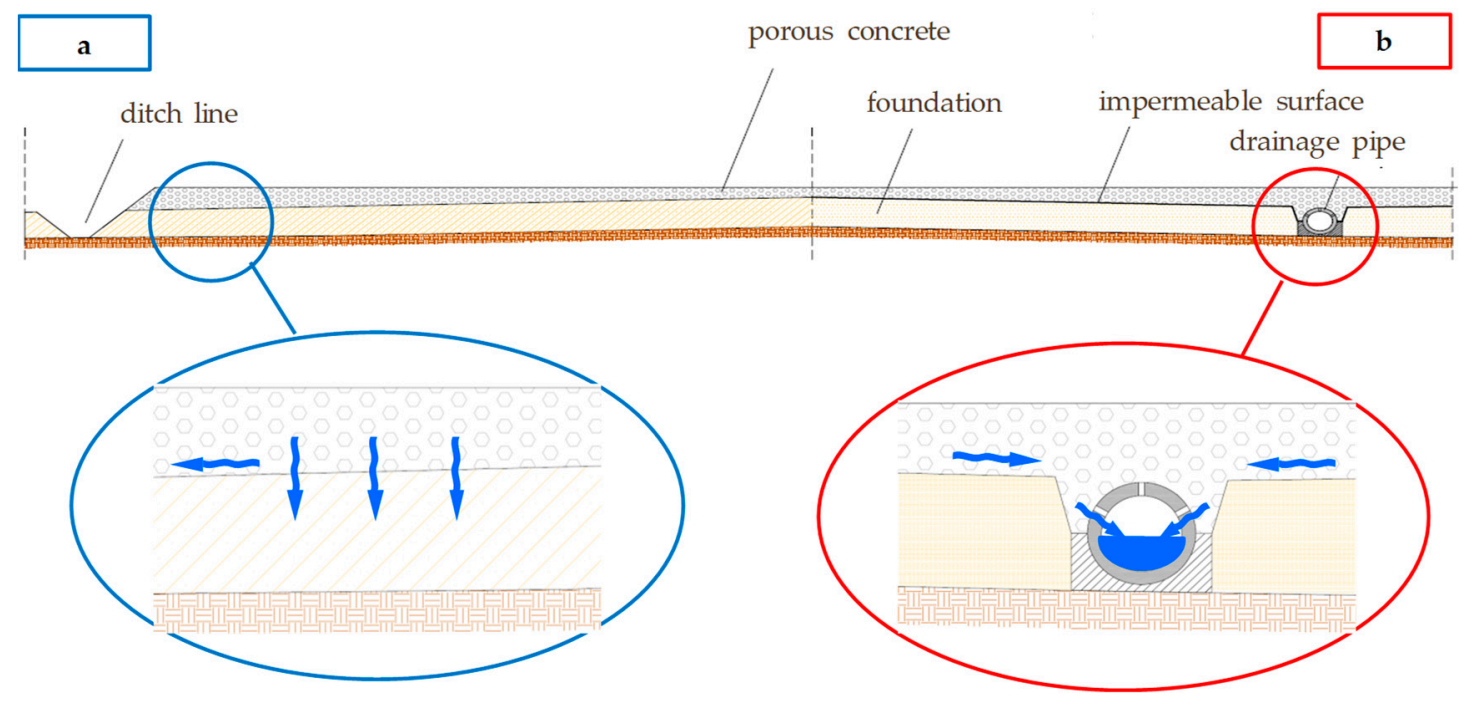

Figure 2. Operating systems of pervious pavements: (a) returning water to aquifers and (b) collecting water in retention basins.

The second operating system is the most frequently adopted in urban areas. Concrete pavement has an average porosity of $20 \%$; for example, a $10 \mathrm{~cm}$ thick concrete layer has a $2 \mathrm{~cm}$ thick storage capacity. Therefore, it could become a temporary basin for rainwater collection and storage in order to relieve pressure on the sewage system. The capillary network of pedestrian areas distributed throughout the city could have a strategic role in mitigating flood risks. Despite the punctual approach of water squares [36,37] and water retention chambers [38,39], which are large underground storage facilities, a porous pavement offers a continuous and distributed system to manage rainwater.

Regarding Figure $1 b$, the overall surface of pedestrian areas (sidewalks, square central islands and areas where motorized vehicles are not allowed, shared areas, and parking lots) is $149,914 \mathrm{~m}^{2}$ (i.e., $5.7 \%$ of the total surface of the quarter), as listed in Table 3.

Table 3. Surfaces in Figure 1.

\begin{tabular}{ccc}
\hline Designated Use & Extension $\mathbf{( m}^{\mathbf{2}} \mathbf{)}$ & Percentage of Surface (\%) \\
\hline Sidewalks & 51,907 & 2 \\
Shared areas & 5622 & 0.2 \\
Squares & 16,183 & 0.6 \\
Parking lots & 76,202 & 2.9 \\
Other (e.g., buildings, carriageways, and green areas) & $2,471,069$ & 94.3 \\
\hline
\end{tabular}

Therefore, porous concrete pavements could store about $3000 \mathrm{~m}^{3}$ of water, which is a volume comparable to existing water storage facilities in Europe [2,40], but this approach does not require any structural and architectural work. Figure 3 shows the designated use of the surfaces displayed in Figure 1. The uniform distribution of potential porous surfaces (i.e., red areas of parking and squares, and blue areas of sidewalks and shared areas) represents the success of the approach, which could omit the study of superficial slopes which instead depend on punctual features. 


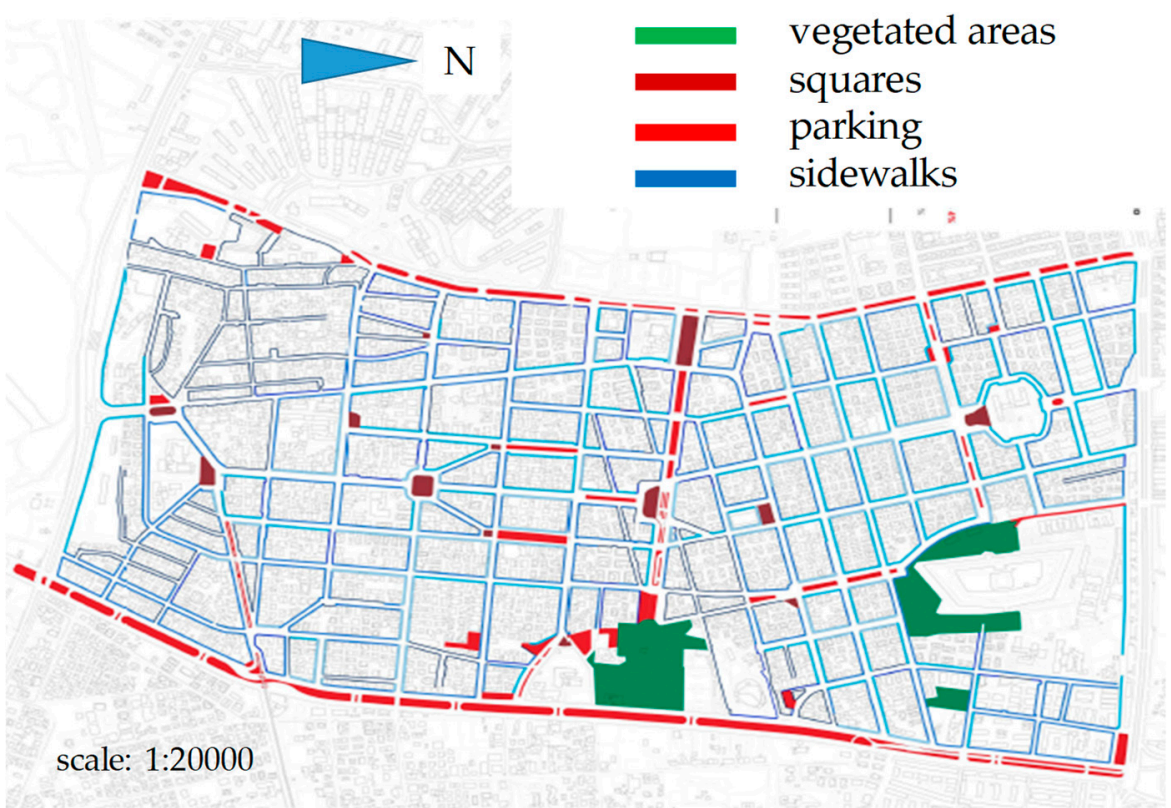

Figure 3. Designated use of urban surfaces shown in Figure 1.

When modular pavements are built, block patterns affect both the structural response [41] and the permeability of the pavement [42]. The design of modular pavements in shared areas should comply with the design criteria adopted for continuous pavements: analysis of traffic loads, identification of the load-bearing capacity of the subgrade, and verification of fatigue damage in bound materials and rutting damage in unbound materials. Moreover, the vertical, rotational, and horizontal interlock of pavers should be verified because the inability of a block moving in isolation from its neighbors prevents premature functional decay of the pavement service life [43]. Regarding parallelepiped blocks (Figure 4), vertical loads (both symmetrically and asymmetrically applied to blocks) and horizontal forces induced by vehicles braking and accelerating cause paver displacements irrespective of the original laying pattern. Moreover, joint gaps should be $3-5 \mathrm{~mm}$ wide to permit joint filling and to ensure pavement durability [41].

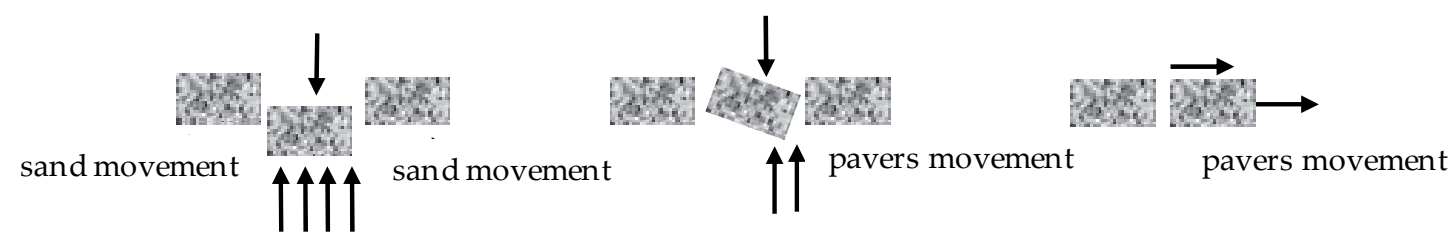

lack of vertical interlock

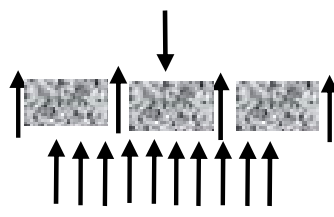

vertical interlock lack of rotational interlock

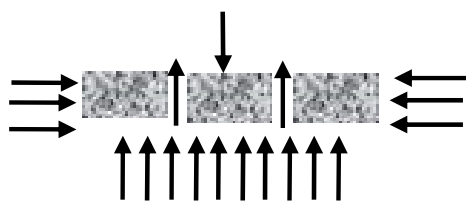

rotational interlock lack of horizontal interlock

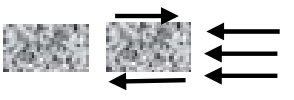

horizontal interlock

Figure 4. Block interlock.

A stretcher or running bond provides the worst mechanical performance in terms of fatigue and rutting resistance, while herringbone bond schemes ensure the best results in terms of durability (Figure 5). 


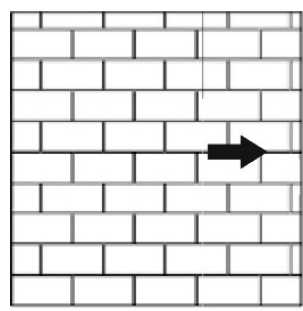

Stretcher or running bond

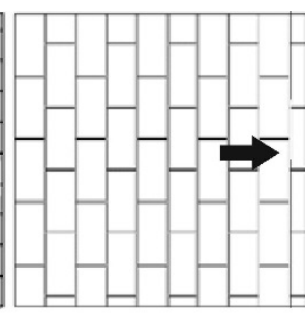

$90^{\circ}$ stretcher or running bond

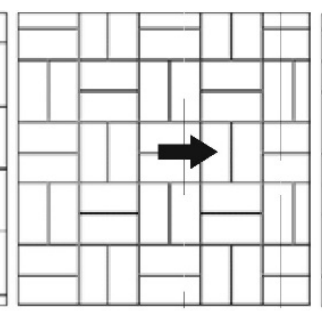

Basket weave or parquet bond

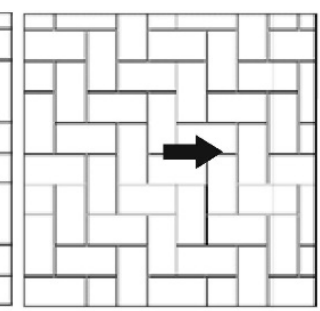

Herringbone bond

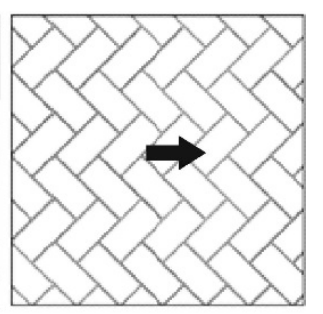

$45^{\circ}$ herringbone

Figure 5. Block patterns.

Permeable interlocking concrete pavers are elements that can be laid out in an interlocking grid pattern, with in-between spaces commonly filled with grass or small stones. Even nonpermeable blocks can ensure interesting values for permeable surfaces (Figure 6): up to an 18\% permeable surface can be achieved by varying the block pattern and the position of the paving spacers. The stretcher (or running) bond and staggered stretcher (or running) bond provide the best performances.

Layout 1

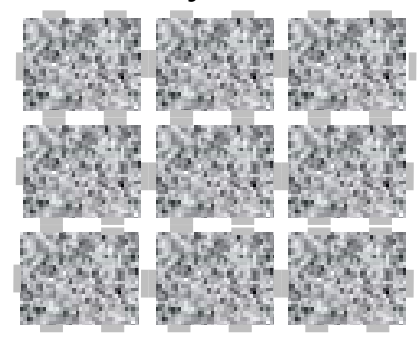

$18 \%$ gaps

Layout 3

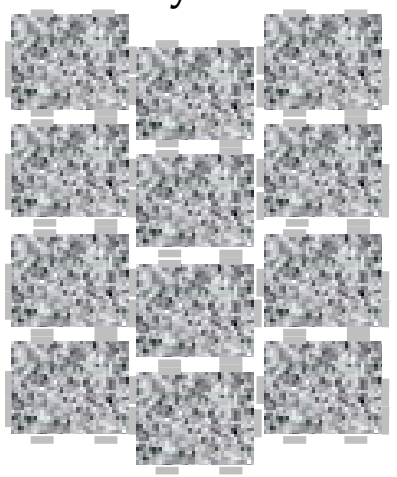

$13 \%$ gaps

\section{Layout 2}

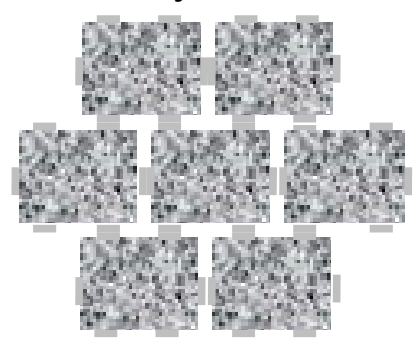

$18 \%$ gaps

\section{Layout 4}

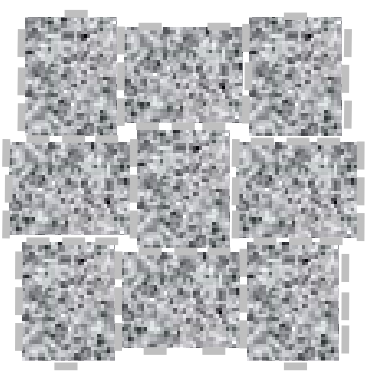

$7.6 \%$ gaps

Figure 6. Permeability vs block pattern.

Finally, the influence of clogging on the effective service life and performance of porous concrete pavements cannot be overlooked [44]. The main causes of clogging are sediments being ground into the pores before being washed off, waterborne sediments which drain onto the pavement and clog pores before being washed off, and structural damages which result in collapsing pores [45]. However, the pore structure of the surface material affects the potential for clogging [16]: the greater the tortuosity (i.e., the ratio of the actual flow path length to the straight distance between the ends of the flow path [46]), the greater the potential for clogging. Therefore, both the design of aggregate gradation and the installation works require attention in order to manage storm flows [32]. 
Surface infiltration tests indicate that porous concrete pavements (both monolithic and modular) have higher infiltration capacity than porous asphalt pavements [47]. Sañudo-Fontaneda et al. [48] measured the permeability of 37 car park bays paved with porous concrete, porous asphalt, and interlocking concrete blocks. After a nine-year service life without maintenance, the surfaces composed of porous mixtures were completely clogged and ended their functional service life, while the permeability of interlocking concrete blocks was halved.

After a simulated 35-year service life, foreign particles were found to seriously reduce the hydraulic conductivity: reductions of $59 \%-75 \%$ caused by an average sediment retention of $94 \%$ were observed. Scan images revealed that most of the clogging occurred up to $25 \mathrm{~mm}$ below the pavement surfaces, sometimes up to $100 \mathrm{~mm}$ [49]. Yong et al. [50] observed the influence of variable inflow and drying periods on hydraulic resistance. Therefore, scheduled cleaning is needed to remove coarse and organic sediment loads in order to maintain hydraulic conductivity [33]. Sansalone et al. [51] found that vacuuming and sonication could recover the initial (clean-bed) hydraulic conductivity of a cementitious permeable pavement. In their study, quarterly maintenance was required to maintain a hydraulic conductivity of at least $0.02 \mathrm{~mm} / \mathrm{s}$.

\section{Discussion}

Events as a consequence of weather and climatic processes raise the need to foresee adaptive measures for climate change; for example, extreme heat events (e.g., heat waves) and thunderstorms will become more frequent in many areas. These climate change challenge have serious consequences in urban areas where growing development has led over the years to a dramatic decrease in natural drainage surfaces. Therefore, visibly negative effects, especially for surface water flows, have occurred, and new artificial surfaces are often composed of dark pavement materials which significantly contribute to UHIs.

Waterproof surfaces (e.g., roofs and road pavements) increase the flow of water into sewage systems. Most of our cities are still served by a single drainage network that collects stormwater runoff and sewage, which can have undesired consequences. Therefore, hazardous floods with consequent overflow of public sewers and sudden changes in the flow rates of waterways are increasing. Moreover, water overload sewage can jam treatment plants, so that sediments and potentially polluting substances on impermeable surfaces are not correctly processed. Finally, impermeable pavements affect the entire ecosystem: underground aquifers are not refilled and surface temperatures increase due to the heat island effect.

Different road pavement materials could address the need for permeability and UHI prevention because the best performing alternatives are permeable features. Particularly, concrete for pedestrian pavements helps to reduce UHI effects because of its high SRI; the material is able to reflect solar energy from its surface back into the atmosphere. Therefore, the surface is "cold" if compared to traditional pavements composed of bituminous mixtures. For porous mixes, this thermal performance is enhanced by porosity. When the pavement temperature increases, the pore water evaporates and subtracts heat from the pavement, thus reducing its surface temperature. Regarding rainwater management, two design approaches could be pursued when designing a SUDS: returning water to underground aquifers, and reducing runoff and collecting water in retention basins. The second one is more effective for managing suspended solids and pollutants; thus, it is the most frequently adopted choice for road surfaces. The implementation of this approach to sidewalks and low-load pavements could add up to a $6 \%$ increase in new permeable surfaces to existing urban areas, where permeable surfaces make up about $20 \%$ of the area.

Different technical solutions could be adopted, as both monolithic and modular pavements permit the achievement of thermal and hydraulic benefits in urban areas. Due to their architectural and aesthetic value, pavers are usually used in places of historical, artistic, and cultural interest. However, the design approach cannot overlook the fact that the laying pattern of modular solutions affects 
the permeable and mechanical performances of these pavements, especially when they are built in shared areas.

On the other hand, regardless of the construction method, porous concrete pavements suffer from clogging because foreign particles reduce hydraulic conductivity. Therefore, scheduled cleaning is needed to remove sediments in order to maintain pavement efficiency.

Author Contributions: Conceptualization, P.D.M. and L.M.; methodology, L.M.; formal analysis, C.F.; investigation, P.D.M. and L.M.; data curation, C.F.; writing-original draft preparation, P.D.M. and L.M.; writing-review and editing, P.D.M. and L.M.

Funding: This research received no external funding.

Conflicts of Interest: The authors declare no conflict of interest.

\section{References}

1. Kousa, H.; Holt, E. Development of durable pervious concrete for Finland's stormwater management needs. In Proceedings of the Concrete Innovation Conference 2014 CIC2014, Oslo, Sweden, 11-13 June 2014.

2. Moretti, L.; Loprencipe, G. Climate change and transport infrastructures: State of the art. Sustainability 2018, 10, 4098. [CrossRef]

3. Buroni, C. Progetto di Rigenerazione Urbana del Quartiere Prenestino-Centocelle a Roma. Master's Thesis, Sapienza University, Rome, Italy, 2017.

4. Vogel, J.R.; Moore, T.L.; Coffman, R.R.; Rodie, S.N.; Hutchinson, S.L.; McDonough, K.R.; McMaine, J.T. Critical review of technical questions facing low impact development and green infrastructure: A perspective from the Great Plains. Water Environ. Res. 2015, 87, 849-862. [CrossRef] [PubMed]

5. Zahmatkesh, Z.; Burian, S.J.; Karamouz, M.; Tavakol-Davani, H.; Goharian, E. Low-impact development practices to mitigate climate change effects on urban stormwater runoff: Case study of New York City. J. Irrig. Drain. Eng. 2014, 141, 04014043. [CrossRef]

6. Razzaghmanesh, M.; Beecham, S.; Kazemi, F. The role of green roofs in water sensitive urban design in South Australia. In Proceedings of the 7th International Conference on Water Sensitive Urban Design, Melbourne, Australia, 21-23 February 2012.

7. Italian Ministry of the Environment. Adozione dei Criteri Ambientali Minimi per l'Affidamento di Servizi di Progettazione e Lavori per la Nuova Costruzione, Ristrutturazione e Manutenzione di Edifici Pubblici; Italian Ministry of the Environment: Rome, Italy, 11 October 2017.

8. Weiss, P.T.; Kayhanian, M.; Gulliver, J.S.; Khazanovich, L. Permeable pavement in northern North American urban areas: Research review and knowledge gaps. Int. J. Pavement Eng. 2019, 20, 143-162. [CrossRef]

9. Loprencipe, G.; Mascio, P.D.; Moretti, L.; Zoccali, P. Analytical and numerical approaches for design of stone pavers in urban shared areas. In IOP Conference Series: Materials Science and Engineering; IOP Publishing: Bristol, UK, 2019; Volume 471.

10. Miccoli, S.; Finucci, F.; Murro, R. Social evaluation approaches in landscape projects. Sustainability 2014, 6, 7906-7920. [CrossRef]

11. Assobeton, 2011. Linee Guida per la Determinazione Della Capacità Drenante Delle Pavimentazioni Modulariin Calcestruzzo. Volume 3 Drenanti. Available online: http://www.assobeton.it/ASSOBETON/ gestsito_new.nsf/324BA2457502EF60C1257A83004242B3/\$FILE/Volume_3_Drenanti_low.pdf (accessed on 15 July 2019).

12. Corazza, M.V.; Mascio, P.D.; Moretti, L. Management of sidewalk maintenance to improve walking comfort for senior citizens. WIT Trans. Built Environ. 2018, 176, 195-206.

13. Doulos, L.; Santamouris, M.; Livada, I. Passive cooling of outdoor urban spaces: The role of materials. Energy 2004, 77, 231-249. [CrossRef]

14. Coseo, P.; Larsen, L. Cooling the heat island in compact urban environments: The effectiveness of Chicago's green alley program. Procedia Eng. 2015, 118, 691-710. [CrossRef]

15. Haselbach, L.; Boyer, M.; Kevern, J.T.; Schaefer, V.R. Cyclic heat island impacts on traditional versus pervious concrete pavement systems. Transp. Res. Rec. 2011, 2240, 107-115. [CrossRef]

16. Kia, A.; Wong, H.S.; Cheeseman, C.R. Clogging in permeable concrete: A review. J. Environ. Eng. 2017, 193, 221-233. [CrossRef] [PubMed] 
17. Kitchenham, B. Procedures for Performing Systematic Reviews; Keele University: Keele, UK, 2004; Volume 33, pp. 1-26.

18. van Wee, B.; Banister, D. How to write a literature review paper? Transp. Rev. 2016, 36, 278-288.

19. Yang, Z.; Ma, W.; Shen, W.; Zhou, M. The aggregate gradation for the porous concrete pervious road base material. J. Wuhan Univ. Technol. Mater. Sci. Ed. 2008, 23, 391-394. [CrossRef]

20. Sriravindrarajah, R.; Wang, N.D.H.; Ervin, L.J.W. Mix design for pervious recycled aggregate concrete. Int. J. Concr. Struct. Mater. 2012, 6, 239-246. [CrossRef]

21. Eathakoti, S.; Gundu, N.; Ponnada, M.R. An innovative no-fines concrete pavement model. IOSR J. Mech. Civ. Eng. 2015, 12, 34-44.

22. Maawali, M.S.N.A.; Reddy, N.S.; Al-Hatali, E.M.A. A study on mechanical properties of porous concrete for its use in low traffic volume roads and parking areas in Muscat. SSRG Int. J. Civ. Eng. 2017, 4, 27-33.

23. Harish, E. Flexural strength behaviour of pervious concrete towards conventional concrete. Int. J. Adv. Inf. Sci. Technol. 2017, 6, 50-69.

24. Zoccali, P.; Moretti, L.; Di Mascio, P.; Loprencipe, G.; D'Andrea, A.; Bonin, G.; Teltayev, B.; Caro, S. Analysis of natural stone block pavements in urban shared areas. Case Stud. Constr. Mater. 2018, 8, 498-506. [CrossRef]

25. Conpaviper. Codice di Buona Pratica per Pavimentazioni in Calcestruzzo Drenante; Conpaviper: Rome, Italy, in press.

26. ASTM International, ASTM D3385-03. Standard Test Method for Infiltration Rate of Soils in Field Using Double-Ring Infiltrometer; ASTM International: West Conshohocken, PA, USA, 2003.

27. United States Environmental Protection Agency. Infiltration through Disturbed Urban Soilsand Compost-Amended Soil Effects on Runoff Quality and Quantity; United States Environmental Protection Agency, Office of Research and Development: Washington, DC, USA, 1999.

28. European Committee for Standardization (EN), EN 12697-40:2012. Bituminous Mixtures. Test Methods for Hot Mix Asphalt in Situ Drainability; European Committee for Standardization: Brussels, Belgium, 2012.

29. Abdel-Aziz, D.M.; Al-Maani, D.O.; Al-Azhari, W. Using pervious concrete for managing storm water run-off in urban neighborhoods: Case of Amman. Am. Int. J. Contemp. Res. 2015, 5, 78-86.

30. Imran, H.M.; Akib, S.; Karim, M.R. Permeable pavement and stormwater management systems: A review. Environ. Technol. 2013, 34, 2649-2656. [CrossRef] [PubMed]

31. Drake, J.A.P.; Bradford, A.; Marsalek, J. Review of environmental performance of permeable pavement systems: State of the knowledge. Water Qual. Res. J. Can. 2013, 48, 203-222. [CrossRef]

32. Fassman, E.A.; Blackbourn, S. Urban runoff mitigation by a permeable pavement system over impermeable soils. J. Hydrol. Eng. 2010, 15, 475-485. [CrossRef]

33. Dierkes, C.; Lohmann, M.; Becker, M.; Raasch, U. Pollution retention of different permeable pavements with reservoir structure at high hydraulic loads. In Proceedings of the 10th International Conference on Urban Drainage, Copenhagen, Denmark, 21-26 August 2005.

34. Tota-Maharaj, K.; Scholz, M. Efficiency of permeable pavement systems for the removal of urban runoff pollutants under varying environmental conditions. Environ. Prog. Sustain. Energy 2010, 29, 358-369. [CrossRef]

35. Abdollahian, S.; Kazemi, H.; Rockaway, T.; Gullapalli, V. Stormwater quality benefits of permeable pavement systems with deep aggregate layers. Environments 2018, 5, 68. [CrossRef]

36. Charlesworth, S.M.; Beddow, J.; Nnadi, E.O. The fate of pollutants in porous asphalt pavements, laboratory experiments to investigate their potential to impact environmental health. Int. J. Environ. Res. Public Health 2017, 14, 666. [CrossRef] [PubMed]

37. de Urbanisten, D.E. Water square Benthemplein in Rotterdam, the Netherlands. Landsc. Arch. Front. 2013, 1, 136-143. Available online: http://www.urbanisten.nl/wp/?portfolio=waterpleinen (accessed on 5 July 2019).

38. Verhoeven. Rotterdam Climate Proof. 2015. Available online: http://www.rotterdamclimateinitiative.nl/ documents/2015-en-ouder/Documenten/ROTTERDAM\%20CLIMATE\%20PROOF\%20ADAPTATION\% 20PROGRAMME\%202013.pdf (accessed on 14 July 2019).

39. Velasco, M.; Russo, B.; Cabello, A.; Termes, M.; Sunyer, D.; Malgrat, P. Assessment of the effectiveness of structural and nonstructural measures to cope with global change impacts in Barcelona. Flood Risk Manag. 2016, 11, 55-68. [CrossRef]

40. Saurí, D.; Palau-Rof, L. Urban drainage in Barcelona: From hazard to resource? Water Altern. 2017, 10, 475-492. 
41. Mascio, P.D.; Moretti, L.; Capannolo, A. Concrete block pavements in urban and local roads: Analysis of stress-strain condition and proposal for a catalogue. J. Traffic Transp. Eng. (Engl. Ed.) 2019. [CrossRef]

42. Fassman, E.A.; Blackbourn, S.D. Road runoff water-quality mitigation by permeable modular concrete pavers. J. Irrig. Drain. Eng. 2011, 137, 720-729. [CrossRef]

43. Loprencipe, G.; Pantuso, A. A specified procedure for distress identification and assessment for urban road surfaces based on PCI. Coatings 2017, 7, 65. [CrossRef]

44. Pezzaniti, D.; Beecham, S.; Kandasamy, J. Influence of clogging on the effective life of permeable pavements. Water Manag. 2009, 162, 211-220. [CrossRef]

45. Scholz, M.; Grabowiecki, P. Review of permeable pavement systems. Build. Environ. 2017, 42, 3830-3836. [CrossRef]

46. Bear, J. Dynamics of Fluids in Porous Media; American Elsevier Publishing Co.: New York, NY, USA, 1988.

47. Razzaghmanesh, M.; Beecham, S. A review of permeable pavement clogging investigations and recommended maintenance regimes. Water 2018, 10, 337. [CrossRef]

48. Sañudo-Fontaneda, L.A.; Andres-Valeri, V.C.; Costales-Campa, C.; Cabezon-Jimenez, I.; Cadenas-Fernandez, F. The long-term hydrological performance of permeable pavement systems in northern Spain: An approach to the "end-of-life" concept. Water 2018, 10, 497. [CrossRef]

49. Kayhanian, M.; Anderson, D.; Harvey, J.T.; Jones, D.; Muhunthan, B. Permeability measurement and scan imaging to assess clogging of pervious concrete pavements in parking lots. J. Environ. Manag. 2012, 95, 114-123. [CrossRef] [PubMed]

50. Yong, C.; Carthy, D.M.; Deletic, A. Predicting physical clogging of porous and permeable pavements. J. Hydrol. 2013, 481, 48-55. [CrossRef]

51. Sansalone, J.; Kuang, X.; Ying, G.; Ranieri, V. Filtration and clogging of permeable pavement loaded by urban drainage. Water Res. 2012, 46, 6763-6774. [CrossRef] [PubMed]

(C) 2019 by the authors. Licensee MDPI, Basel, Switzerland. This article is an open access article distributed under the terms and conditions of the Creative Commons Attribution (CC BY) license (http://creativecommons.org/licenses/by/4.0/). 